Journal of American Studies, 49 (2015), 3, 541-556

(C) Cambridge University Press and British Association for American Studies 2014. This is an Open Access article, distributed under the terms of the Creative Commons Attribution licence (http://creativecommons.org/licenses/by/3.0/), which permits unrestricted re-use, distribution, and reproduction in any medium, provided the original work is properly cited.

doi:10.1017/S0021875814001844 First published online I 2 November 2014

\title{
A Jewish American Monster: Stanley Kubrick, Anti-Semitism and Lolita (1962)
}

\author{
NATHAN ABRAMS
}

This article presents a case study of the filmmaker Stanley Kubrick, considering how his films can be considered an emotional response to the Holocaust, the legacy of European antiSemitism, and stereotypes of the Jewish American woman. It will argue that there are various clues in Kubrick's films which produce Jewish moments; that is, where, through a complementary directing and acting strategy, in particular one of misdirection, the viewer is given the possibility of "reading Jewish," albeit not with certainty, for Jewishness is "textually submerged." Its focus is Kubrick's 1962 adaptation of Vladimir Nabokov's Lolita (1955), in particular the character of Charlotte Haze, played by Shelley Winters, especially in light of Kubrick's choice of casting for the role, and Winters's subsequent performance of it. It will conclude that Holocaust and anti-Semitic stereotypes/reverse stereotypes haunt Kubrick's version of Lolita as an emotional, yet sub-epidermis, presence.

\section{INTRODUCTION}

Filmmaker Stanley Kubrick was rarely thought of as a Jewish director who made Jewish films (however that may be defined). Yet, born in 1928, and growing up as the Holocaust was taking place in Europe, the awareness of the inescapability of his Central European Jewish heritage arguably had a significant emotional impact upon him. Although Kubrick said very little about the Holocaust, its presence is felt in his films, but it is approached obliquely, often via analogies and metaphors, sometimes by overt, albeit brief, moments which explore the very same issues raised by the Shoah. Frederic Raphael, who collaborated with Kubrick on the screenplay for his final film, Eyes Wide Shut (1999), suggested, "S. K. proceeds by indirection ... [his] work could be viewed, as responding, in various ways, to the unspeakable (what lies beyond spoken explanation).” And John Orr and Elżbieta Ostrowska have pointed out, "Kubrick, who never realised his Holocaust film project, nonetheless had a

SCSM, Bangor University. Email: n.abrams@bangor.ac.uk.

${ }^{\text {I }}$ Frederic Raphael, Eyes Wide Open: A Memoir of Stanley Kubrick (London: Orion, I 999), I 50 ; see also Geoffrey Cocks, "Indirected by Stanley Kubrick," Post Script, 32, 2 (2014), 22-35. 
post-Holocaust vision of the contemporary world." 2 This may well have been amplified by his third marriage, in 1958 , to Christiane Harlan, the niece of Veit Harlan, who had directed the notoriously anti-Semitic propaganda film, Jud Süss in 1940. Kubrick had met Harlan in 1957 and wanted to make a film about him, and Kubrick therefore was surely sensitive to the impact on the Harlan family of Harlan's decision to work so closely with the Nazi leadership. ${ }^{3}$

How this post-Holocaust sensibility operated in Kubrick's films will be explored via a detailed case study of a key character in one of his films, namely Charlotte Haze, played by Shelley Winters, in his 1962 adaptation of Vladimir Nabokov's Lolita (1955). ${ }^{4}$ She has been chosen because in casting and performance Winters's real-life Jewishness and her performance of Haze's onscreen persona provide a key prism through which to consider Kubrick's own ethnicity and attitudes towards it, as well as his post-Holocaust sensibility, at a crucial stage in his career and in postwar Hollywood. It will be argued here that, if, as Daniel Anderson has suggested, "The language and the visible world of Lolita are so deeply conditioned by their post-Holocaust circumstances," then they must have also influenced Kubrick.5 Consequently, the Holocaust haunts his version of Lolita as an emotional, yet submerged, presence, producing an intriguing representation of the Jewish American Mother.

Scholars have already detected the novel's underlying concerns with the Holocaust. ${ }^{6}$ Susan L. Mizruchi, for example, has elucidated the novel's "holocaust subtext"; that is, "a consistent pattern of references to Nazi persecution and genocide in Europe." 7 Many of the metaphors and descriptions in the novel evoke the trains, camps, and other details of the Holocaust, both

${ }^{2}$ John Orr and Elżbieta Ostrowska, The Cinema of Roman Polanski: Dark Spaces of the World (London: Wallflower, 2006), I 42.

${ }^{3}$ Geoffrey Cocks, The Wolf at the Door: Stanley Kubrick, History, and the Holocaust (New York: Peter Lang, 2004), 70.

${ }^{4}$ Reasons of length preclude a consideration of other characters and elements in the film, especially those that are also integral to a post-Holocaust sensibility. This may include a reckoning with the relationship between sexuality and perversity and "Jewishness," so central to anti-Semitism as played out through Humbert in particular. The casting of Peter Sellers was yet another interesting and significant casting choice; Seller's maternal Jewishness was also, I would argue, important to his selection. Furthermore, there are many possible ways and "coded clues" to reading his character/performance as Jewish. In both cases, then, there is certainly the implication that Humbert and Quilty might also be coded as Jewish, connecting their "inappropriate" sexuality to anti-Semitism.

5 Douglas Anderson, "Nabokov's Genocidal and Nuclear Holocausts in 'Lolita'," Mosaic, 29, 2 (1996), 75-89, 82.

" Jerold J. Abrams, "The Logic of Lolita: Kubrick, Nabokov, and Poe," in Abrams (ed.), The Philosophy of Stanley Kubrick (Lexington: University of Kentucky Press, 2007), 109-29; Susan L. Mizruchi, "Lolita in History," American Literature, 75, 3 (2003), 629-52; Andrea Pitzer, The Secret History of Vladimir Nabokov (New York: Pegasus, 20 13).

${ }^{7}$ Mizruchi, 63 I. 
directly and subtextually. Nabokov refers to "the brown wigs of tragic old women who had just been gassed" or "the ashes of our predecessors." In I 935, the year of Lolita's fictive birth, Hitler passed the Nuremberg Laws and Anderson reads an imaginative equation between the Nazis' obsession with race and therefore sexual reproduction and Humbert's paedophilia, while Mizruchi posits that Humbert's "case" parallels the ongoing trials of Nazi war criminals in Nuremberg from 1946 to 1949.9 The repetition of twins and twinning in the novel - the twin beds and the picture of twins in the motel, the twin girls in blue bathing suits who almost discover Lolita and Humbert Humbert (itself a twinned name), the four pairs of twins in Lolita's class list (at least one of whom, "Cowan", may be read as Jewish as it was common to alter the name "Cohen" to that) - evokes the notorious pseudoscientific medical experiments of Dr. Josef Mengele at Auschwitz. Kubrick would later go on to make use of twins in The Shining (1980), which like the famous Diane Arbus photograph Identical Twins (1967) that inspired him, also prompts audience reference to Mengele and Auschwitz. ${ }^{10}$

Mizruchi also observes Lolita's "attention to American anti-Semitism." ${ }_{11}$ Humbert is often mistaken for being Jewish. Before marrying him, Charlotte first wants to find out precisely how "foreign" Humbert is: "Looking down at her fingernails, she also asked me had I not in my family a certain strange strain." She can tolerate a "Turk" as one of his ancestors, as long as he himself is truly Christian; however, "if she ever found out I did not believe in Our Christian God, she would commit suicide." 12 Likewise, her friends, John and Jean Farlow, also have a vague suspicion he may be Jewish because of his dark looks and exotic name. So when John is about to make disparaging remarks about Jews in Humbert's presence, "Of course, too many of the tradespeople here are Italians ... but on the other hand we are still spared," she cuts him off. ${ }^{13}$ Humbert attempts to check in to the Enchanted Hunters Hotel but is initially refused entry because it is restricted, advertising itself as being "Near Churches," ${ }^{4} 4$ a coded expression used in adverts to indicate its discriminatory, restrictive practices. ${ }^{15}$ Nabokov also makes continuous use in the novel of the number 42, as the workings of what Humbert regarded as "McFate" stalking him to his doom. The number also recurs in his Lolita screenplay. ${ }^{16}$ Cocks suggests that 42 was "conscious and unconscious cultural shorthand

\footnotetext{
${ }^{8}$ Vladimir Nabokov, Lolita (London: Transworld, 1961; first published 1955), 267, 2 10.

${ }^{9}$ Anderson, 78-79; Mizruchi, 637.

${ }^{10}$ See also Cocks, "Indirected," 28-29, on Kubrick's use in The Shining of a painting by Paul Peel, After the Bath ( 1890 ), which depicts two naked little girls in front of a fireplace.

${ }^{11}$ Mizruchi, 639.

${ }^{13}$ Ibid., 83-84.

${ }^{12}$ Nabokov, 79 .

${ }^{14}$ Ibid., 275 .

${ }^{15}$ Alfred Appel Jr. (ed.), The Annotated "Lolita" (London: Penguin, I97I), 423.

${ }^{16}$ See Cocks, The Wolf at the Door, 103 for a full list.
} 
for the Holocaust." ${ }^{17}$ Consequently, Anderson argues that "the novel's rich amalgamation of post-war America with pre-war Europe" evokes the "unbearable memory of genocidal holocaust." ${ }^{8} 8$ Yet Kubrick omitted many of these details, consistent with his practice of writing Jews out of his films, although he did reference them indirectly by various means. For example, he did use 242 as the number of the room at the Enchanted Hunters Hotel in which Lolita and Humbert first have sex (and 42 as a reference to the Holocaust throughout The Shining, which is set in the haunted Overlook Hotel).

These concerns may have been one of the motivating factors behind Kubrick's desire to film the novel in the first place, although, given his refusal to be explicit on the subject, we will never know for certain. Kubrick solicited writer Calder Willingham to produce a screenplay, but Kubrick rejected it on the grounds that it was "not worthy" of the book, its "most serious fault not realizing characters." 19 Kubrick subsequently approached Nabokov himself, telling him, "you are only one for screen play. If financial details can be agreed would you be available quick start for May I Production appreciate cable." 20 Nabokov then began the laborious task of adapting his own novel, producing various draft screenplays, little of which Kubrick ultimately used. ${ }^{21}$ Instead, what became the final screenplay was written by Kubrick and his producer, James B. Harris, using the book, Nabokov's various drafts, and their own ideas, as well as those generated from the rehearsals and the process of shooting itself. Nonetheless, they decided to give the screenwriting credit to Nabokov. ${ }^{22}$

The Holocaust was much in the news and in popular culture at precisely the same time as the film was in preproduction. The Diary of Anne Frank had been published and serialized in the leading New York intellectual magazine Commentary in $1952 .{ }^{23}$ It was subsequently adapted for the stage, and then made into the 1959 film (directed by George Stevens) for which Winters won the Oscar for Best Supporting Actress. The following year, in 1960, highranking Nazi bureaucrat Adolf Eichmann - one the chief architects of the Nazi genocide - was captured in Argentina, kidnapped and transported to Israel, where he was imprisoned while awaiting trial. Incidentally, at some point during his incarceration, one of Eichmann's guards gave him a copy of

${ }^{17}$ Cocks, "Indirected," 29.

${ }^{19}$ Calder Willingham, Lolita screenplay, SK/ro/I/I, the Stanley Kubrick Archives, University of the Arts, London (hereafter SKA); Kubrick, telegram to Vladimir Nabokov, 8 Dec. 1959, MSS Nabokov, the Berg Collection, New York Public Library (hereafter Berg).

${ }^{20}$ Kubrick, telegram to Nabokov, 8 Dec. 1959, Berg.

${ }^{21}$ Nabokov later published his version, enabling comparisons to Kubrick's film.

${ }^{22}$ James B. Harris, interview (Fall 2002), at www.hollywoodfiveo.com/archive/issuez/exclusive/ harris/harris.htm, accessed July 2013.

23 "The Diary of Anne Frank," Commentary, I3, 5 (1952), 419-32; "The Diary of Anne Frank - II," Commentary, I3, 6 (1952), 529-44. 
the recently published German translation of Lolita (1959), as German Jewish émigré philosopher Hannah Arendt puts it, "for relaxation." ${ }^{24}$ After two days Eichmann returned it, visibly indignant, telling his guard, "Quite an unwholesome book."25 (Is it possible that Eichmann rejected Lolita not only because of its sexual content but also because he detected it as being somehow "Jewish"?26) In 1961, Judgment at Nuremberg (Stanley Kramer), with camp footage, was released and Raul Hilberg published his magisterial and groundbreaking Holocaust study, The Destruction of European Jews, which Kubrick subsequently read. ${ }^{27}$ That same year, with much publicity and international attention, Eichmann's trial for war crimes began in Jerusalem. As a result, secular Jewish intellectuals, particularly in the United States, became much more conscious of the devastation of the Holocaust. Furthermore, they were vocal about it, using the Shoah to mould public opinion, increasingly making explicit comparisons between the Nazi genocide and nuclear mass death in the I950s and early i960s. Even Kubrick suggested it in his next film, Dr. Strangelove or: How I Learned to Stop Worrying and Love the Bomb (1964), for example. ${ }^{28}$ The 1960 s were also a time when American Jewish filmmakers began to introduce a wider range of Jewish themes and characters, including the Holocaust, into their films in a fashion not seen since the I920s. 29

Kubrick's decision to cast Shelley Winters as the pseudo-intellectual suburban housefrau, Charlotte Haze, is perhaps the most significant clue to reading this film as an emotional response to his own Jewishness, as well as to the Holocaust, and goes some way to recovering Nabokov's underlying concerns in the novel. It is certainly hard to ignore Winters's own ethnicity and previous roles as a consideration in Kubrick's casting of her as Charlotte. Winters was born Jewish, as Shirley Schrift, in 1923, but took her mother's

${ }^{24}$ Hannah Arendt, Eichmann in Jerusalem: A Report on the Banality of Evil, revised and enlarged edn (New York: Penguin, i 964), 49. See also Leland de la Durantaye, "Eichmann, Empathy, and Lolita," Philosophy and Literature, 30, 2 (2006), 3 I I-28.

${ }^{25}$ Arendt, 49.

${ }^{26}$ However, de la Durantaye, 3 I 2, notes, "given Eichmann's radical conventionality one could hardly imagine him liking - or even very well understanding - much of the book."

${ }^{27}$ In 1975 Kubrick asked his brother-in-law Jan Harlan to read Hilberg's book; in 1980 he sent a copy to Michael Herr, describing it as "monumental." Herr recalled how Kubrick was "absorbed” by it. Michael Herr, Kubrick (London: Pan, 2000), ı, original emphasis; Geoffrey Cocks, "Death by Typewriter: Stanley Kubrick, the Holocaust, and The Shining," in Geoffrey Cocks, James Diedrick and Glenn Perusek (eds.), Depth of Field: Stanley Kubrick, Film, and the Uses of History (Madison: Wisconsin University Press, 2006), 1 85-2 17, 196.

${ }^{28}$ See Jon Petrie, "The Secular Word HOLOCAUST: Scholarly Myths, History, and 2oth Century Meanings," Journal of Genocide Research, 2, I (2000), 3 I-63.

${ }^{29}$ See Patricia Erens's The Jew in American Cinema (Bloomington: Indiana University Press, 1987); and Lester D. Friedman, The Jewish Image in American Film (Secaucus, NJ: Citadel, 1987). 
maiden name. She had already played Natalia Landauer, a German Jewish girl, in I Am a Camera (1955), based on Christopher Isherwood's Berlin Stories (1945), about the doomed intelligentsia in prewar Berlin. Winters had lost an aunt and cousins in the Holocaust: "our family had missing relatives who, we found out later, died in the concentration camps." $3 \circ$ As a result, she refused to film exterior shots in Germany "because I could not reconcile the thought of doing so with the image of my Holocaust-survivor uncle Yaekel." ${ }_{1}$ Winters then played a variety of roles, in which she specialized as lower-class blondes murdered halfway through the film. ${ }^{32}$ Thereafter, she progressed to "more matronly roles." 33 As mentioned above, she eventually won an Oscar for her portrayal of the Jewish refugee Mrs. Petronella Van Daan in The Diary (a part for which she gained twenty-five pounds). From then on, comments J. Hoberman, "Winters would never return to glamour roles."34

Arguably, Winters's role as Van Daan influenced all of her subsequent performances. She recalled,

When we started shooting the film, Stevens had all the adult actors come to a projection room. He showed us the films his unit in the Special Services had taken of the concentration camps. His Army unit had been the first into Dachau. Watching those horrendous films possibly made me play that role so that I won the Oscar, but I believe that shooting that film scarred me for life. I can never read or watch anything about the Holocaust. 35

Winters spent almost six months on the set of The Diary. ${ }^{36}$ "I learned something about acting that I was to use for the rest of my life." 37 She also stated that it was "Anne Frank whose memory and words have inspired me all of my adult life." $3^{8}$ Winters, then, brought what she had learned on The Diary to her performance in Lolita.

Given the prominence and success of this role, only three years before Lolita, it seems impossible to ignore that this was a consideration in her casting. Furthermore, Anderson argues that the circumstances surrounding Lolita "so perfectly reverse" those of the manuscript of Anne Frank that "Nabokov envisioned Lolita as a fictional mirror image, an opposite twin, of her celebrated nonfictional contemporary." $39 \mathrm{He}$ points out that Lolita's

${ }^{30}$ Shelley Winters, Shelley II: Best of Times, Worst of Times (London: Muller, 1990), 55.

${ }^{31}$ Ibid.

${ }^{32}$ These were A Double Life (1947), A Place in the Sun (1952) and Night of the Hunter (1955).

${ }^{33}$ Gene D. Philips and Rodney Hill, The Encyclopedia of Stanley Kubrick (New York: Hill \& Wang, 2002), 400.

${ }^{34}$ J. Hoberman, "Shelley Winters," in J. Hoberman and Jeffrey Shandler (eds.), Entertaining America: Jews Movies, and Broadcasting (Princeton, NJ: Princeton University Press, 2003), I76. $\quad{ }^{35}$ Winters, $55 . \quad{ }^{36}$ Ibid., $224 . \quad{ }^{37}$ Ibid., 233.

${ }^{38}$ Shelley Winters, Shelley: Also Known as Shirley (London: Granada, 1980), 391.

${ }^{39}$ Anderson, 83 . 
forerunner, Annabel Leigh, "died of typhus - the endemic disease of the concentration camps in the closing months of the war, and perhaps not so coincidentally the cause of Anne Frank's death in Bergen-Belsen early in I $945 . " 4^{\circ} \mathrm{He}$ further notes how The Diary appeared in 1952 and Lolita was published in $1955 .^{4 \mathrm{I}}$ In a further twist of uncanny symmetry, The Diary was made into a film in 1959 and Lolita in 1962 - again three years apart - and both featuring Winters as a supporting actress.

Winters also recalled that her Jewishness came through on the set of Lolita. She wrote how, refusing to drop a silk robe with her back to the camera and instead hitting the microphone with her head, mixing up her lines and breaking James Mason's glasses (Mason was playing Humbert), she was named "the klutz", as a specifically Jewish put-down of herself. ${ }^{42}$ Furthermore, she remembered, "At one point, when I was squirming with embarrassment under the covers with just panties on, Mason whispered to me: 'Would it make you feel more comfortable if I tell you that a long time ago my name was Moskowitz, and not Mason?"'43

Winters was certainly essential to Kubrick's thinking; so much so that he was willing to cast her despite the obstacles to doing so. The first potential hurdle was the Eady Levy that came into effect on 9 September 1950, which provided indirect funding to film producers but only if a film qualified as "British." In order to qualify as a British film no less than eighty-five per cent of the film had to be shot in the United Kingdom or the Commonwealth, and only three non-British individual salaries could be excluded from the costs of the film, ensuring the employment of British actors, technicians and film crew. The other two principal actors - Mason as Humbert and Peter Sellers as Clare Quilty - were British where Winters was not, and she had to be flown over and put up at considerable expense. Second, the daily production reports indicate that she proved to be a pain on the set. ${ }^{44}$ "Winters tried Kubrick's patience," wrote Kubrick's biographer, Vincent Lobrutto.45 "Winters was very difficult," recalled Oswald Morris, Lolita's cinematographer,

wanting to do everything her own way. She was very nearly fired off the film. At one point Kubrick said to me, "I think the lady's gonna have to go" - which would have been very serious halfway through production. But he'd have got rid of her, he really didn't care about the consequences. ${ }^{46}$

She was also ill with stomach problems and diarrhoea, delaying the shoot. ${ }^{47}$ Nonetheless, Kubrick persevered with her either because the cost of replacing her so late into the shoot was prohibitive, or because of what Kubrick valued

\footnotetext{
${ }^{40}$ Ibid. $\quad{ }^{41}$ Ibid. $\quad{ }^{42}$ Winters, Shelley II, $349 . \quad{ }^{43}$ Ibid., 350.

44 "Lolita Daily Production Progress Reports," 22 Nov. 1960-29 March 1961, SK/10/3/2, SKA.

${ }^{45}$ Vincent LoBrutto, Stanley Kubrick: A Biography (New York: Donald I. Fine, 1997), 208.

${ }^{46}$ Ibid., 209. $\quad 47$ "Lolita Daily Production Progress Reports."
} 


\section{Nathan Abrams}

that she specifically brought to the role. Frustratingly, however, Kubrick's archives contain no explicit reference to his reasons for casting her, or to her ethnicity, so we will never know for certain what it was that Kubrick specifically valued about what Winters brought to the role.

Although there is no indication in the novel that Charlotte is Jewish, nor is there any other explicit evidence in the film beyond the fact of Winters's own ethnicity and previous roles, a series of clues combine to allow us to read her as Jewish. First, Charlotte is the embodiment of the stereotype of the Jewish American Mother (JAM) that began to emerge in postwar American Jewish literature at exactly the same time as Lolita was published. In 1955 Herman Wouk's best-selling novel Marjorie Morningstar produced a stereotype that would be much copied over the coming years. Unlike her pre-Second World War counterpart, the yiddische Mama, who was viewed with affection, the Jewish Mother was not. She was presented as meddlesome, domineering and controlling. Toward the end of the decade, the Jewish mother and her spoiled suburban daughter became the objects of literary ridicule, as evidenced by Philip Roth's Goodbye Columbus (1959), a template which, in many ways, fitted Charlotte and Lolita Haze. ${ }^{8}$ According to Susan Bordo, Charlotte is "the monster of the story." ${ }^{9}$ Like the JAM, Charlotte is pretentious, irritating, bossy, "a behemoth mom." ${ }^{\circ}$ Charlotte is a baalebusteh who cooks and kibitzes, nagging her daughter incessantly, and henpecking Humbert, as her husband, into desperation and longing for a means of escape. ${ }^{51}$ In return, Humbert describes her as a "brainless ba-ba," a designation attributed to his first wife in Nabokov's novel but attached to Charlotte in the film.

It is surely no coincidence that, following Lolita, Winters was thereafter typecast. She played Jewish women/mothers in A House Is Not a Home (1964), Enter Laughing (1 967), Wild in the Streets (1 968), Buona Sera, Mrs. Campbell (1968), The Poseidon Adventure (1973), Blume in Love (1973) and Next Stop, Greenwich Village (1976). As J. Hoberman put it, "No actress since Gertrude Berg has been more associated with the Jewish mother than Shelley Winters." 52 Significantly, he continues, she "was a Jewish mother for the I 960 s: blowzy, strident, and generally overwhelming." 33 Although Hoberman does not list Lolita in his discussion of Winters, his description neatly fits the role of Charlotte.

${ }^{48}$ See Joyce Antler, You Never Call! You Never Write! A History of the Jewish Mother (New York: Oxford University Press, 2007).

${ }^{49}$ Quoted in Patrick Webster, Love and Death in Kubrick: A Critical Study of the Films from Lolita through Eyes Wide Shut (Jefferson, NC: McFarland, 201 I ), 17.

${ }^{50}$ Richard Corliss, Lolita (London: BFI, I 994), 40.

${ }^{51}$ Incidentally, Winters would play an explicitly Jewish version of this stereotype in Next Stop, Greenwich Village (1976), directed by Paul Mazursky, who acted in Kubrick's very first film, Fear and Desire (1953).

${ }^{52}$ Hoberman, 176.

53 Ibid. 
Charlotte manifests other stereotypical Jewish tics. She is zaftig (Yiddish: plump). Her taste in clothing and interior decoration is vulgar. She wears fur wraps and leopard-print dresses and belts. Her kitchen is hideously decorated with very loud wallpaper covered in food motifs. Similarly, her taste in art and artefacts - a porcelain cat sits on a dresser beneath a painting at which Humbert contemptuously stares - reveals the levels of her vulgarity. Indeed, her house is littered with so many tshatshkes (Yiddish: ornaments, trinkets, knickknacks) that it might well have come straight out of a Mad magazine caricature. She displays a lack of civility and decorum and her body language lacks the required reserve. She stuffs her mouth with a hotdog at the summer dance. She encroaches upon the personal space of others and is unaware of their discomfort. She talks too much and fails to read the cues, particularly when alone with Humbert, who does all he can to reject her sexual advances, which, however, she fails to notice. At one point he simply walks out of the frame and Winters keeps yakking. As Norman Podhoretz wrote, the "association of Jewishness with vulgarity and lack of cultivation" is fairly widespread, "not least among Jews." 54

Furthermore, Charlotte is desperate to hide her origins. Consequently, she is determined to mimic her idea of a cultivated and sophisticated suburbanite. She affects a French accent, referring to Humbert as "Oh M'sieur." She smokes through a cigarette holder. She belongs to a book club, is "Chairman of the great Books Committee," and decorates her house with her idea of high art and artefacts. She name-drops at every opportunity, citing Dufy, Van Gogh, Monet, Schweitzer and Zhivago as evidence of her insistence on just how cultured, progressive and advanced she really is. She informs Humbert, "We're really very fortunate here in West Ramsdale. Culturally, we're a very advanced group with lots of good Anglo-Dutchss and Anglo-Scotch stock and we're very progressive intellectually." At the same time, Charlotte's choice of words, which were taken verbatim from the novel and retained by Kubrick, suggest an implicit postwar racism of the genteel Gentleman's Agreement type in which covenanted neighbourhoods prevented Jews from buying or renting property there.

Charlotte's multiple references to culture reveal her attempt to pass - and to make a pass at Humbert - but in reality they suggest an excess, a trying too hard to be the same but failing, becoming, in Homi Bhabha's famous formulation, "almost the same, but not quite." 56 It is revealed, for example, by

${ }^{54}$ Norman Podhoretz, Making It (New York: Random House, 1967), I61.

${ }^{55}$ Is this a sly reference to the role she played as a Dutch Jewish refugee in Amsterdam in The Diary?

${ }^{56}$ Homi Bhabha, The Location of Culture (London: Routledge, 1994), 123; emphasis in the original. 
the fact that her artworks are merely reproductions or simulacra, as well as by her mispronunciation of the name Van Gogh as "Van Gock." Charlotte's mimicry, which surely can be described as "undisciplined," has long been felt to mark the Jewish condition. For Max Horkheimer and Theodor Adorno, "undisciplined mimicry" was "engraved in the living substance of the dominated and passed down by a process of unconscious imitation in infancy from generation to generation, from the down-at-heel Jew to the rich banker." 57 This was because "Jewish Emancipation involved Jews in collisions with the differentiations of Western society [and] Jews were being asked, in effect, to become bourgeois, and to become bourgeois quickly." ${ }^{8}$ Charlotte here is desperately trying, but failing, to pass by masking her Jewish roots through her failing mimicry (a faux posh accent, use of words, intellectual/ cultural airs and graces), but it is the very excess of her mimicry that gives her away, revealing her failure to pass, and echoing the Jewish saying that "Jews are like everybody else, only more so." As if to stress the point, and to make sure that the translators and dubbing directors understood his intentions, Kubrick annotated the Dialogue Continuity script with instructions. For example, when Humbert is shown around Charlotte's house, Kubrick has written, "Note to translators and dubbing directors: Charlotte Haze's choice of words in English are pretentious and awkwardly pseudo-intellectual. Try to retain that feeling because it is the basis of much of the comedy." When she says, "Oh Paris ... France ... Madame," Kubrick noted, "a good example of her pretentious and awkward choice of words." 59 These mannerisms precisely fit the emerging JAM stereotype of the I950s and 1960s as described by Martha A. Ravits: "she personifies garish ethnic manners and materialistic, middleclass pretensions." ${ }^{60}$ In this respect, it certainly seems very illuminating that Winters drew upon someone she knew (although whom she does not actually reveal) in playing the part of Charlotte. "I had known a pseudointellectual suburbanite like Charlotte, the character I played, during my childhood days in Jamaica, Queens, and Stanley Kubrick knew what acting buttons to press in my acting computer to bring her back." ${ }^{61}$

Charlotte also affects a Christian/Catholic religious identity. In her letter of love and confession to Humbert she writes, "Last Sunday in church, my dear one, when I asked the Lord what do about it ...”. She keeps her late husband's

${ }^{57}$ Max Horkheimer and Theodor Adorno, Dialectic of Enlightenment, trans. John Cumming (London: Allen Lane, i 973), i 82.

${ }^{8}$ John Murray Cuddihy, The Ordeal of Civility: Freud, Marx, Lévi-Strauss, and the Jewish Struggle with Modernity (Boston: Beacon, 1978), I 2-1 3.

59 "Lolita" Dialogue Continuity, Sept. 1961, labelled "S. Kubrick corrected copy," containing notes to translators and dubbing directors, $\mathrm{SK} / \mathrm{I} \mathrm{o} / 3 / 3$, SKA.

${ }^{60}$ Martha A. Ravits, "The Jewish Mother: Comedy and Controversy in American Popular Culture," MELUS, 25, I (2000), 3-3 I, 8.

${ }^{61}$ Winters, Shelley, $40 \mathrm{I}$. 
ashes in an urn on a sideboard, in a bedroom shrine, complete with a crucifix and flanked by Catholic icons, as if copying Tennessee Williams in Rose Tattoo, noted the Brooklyn Tablet. ${ }^{62}$ This display again reveals the excess of her mimicry, for arguably only a Jew could conceive of such a Christian/Catholic shrine and indeed the shrine is the product of the Jewish imagination: Kubrick's. Furthermore, as the Brooklyn Tablet further noted, while Charlotte "prattles about God" she "gives daughter Lolita neither religious training nor good example." ${ }^{3}$ As if recognizing this fact, John Baxter has written that Kubrick replaced a crucifix with a triptych of Our Lady of Perpetual Succour, following complaints about the juxtaposition of Mr. Haze's ashes with a crucifix in Charlotte's bedroom, resulting in "a Byzantine image that probably looked sufficiently exotic to count as Jewish or Middle European." ${ }^{64}$ Making Charlotte Catholic/Christian and have her attend church is Kubrick's misdirection.

Where the novel, as mentioned above, was full of allusions, both direct and indirect, to the Second World War and the Holocaust, the film removes these, but their traces remain. The one explicit remaining reference is when Charlotte tells Lolita (Sue Lyon) off and orders her not to disturb "Professor Humbert." In reply Lolita mimics a Hitler salute, albeit with her left hand, and says "Sieg heil." As if responding to the gesture, in the scene that immediately follows, Charlotte informs Humbert that she has been "too liberal" and is sending Lolita off "long-distance" to a "camp" for "isolation." The phraseology here, through its close juxtaposition with the direct invocation of Hitler, uncannily echoes the Nazis' euphemistic language ("final solution," "solution possibilities," "special treatment," "cleansing operation," "deportation," "displacement," "resettlement," and "evacuation"),65 as well as anticipating Betty Friedan's striking comparison of Nazi concentration camps to American suburban homes one year later. In one of the most potentially shocking passages of her The Feminine Mystique (1963), Friedan claimed that "the women who 'adjust' as housewives, who grow up wanting to be 'just a housewife,' are in as much danger as the millions who walked to their own death in

${ }^{62}$ The Tablet (Brooklyn), 3 June 1962, SK/10/6/3i, SKA. $\quad{ }^{63}$ Ibid.

${ }^{64}$ John Baxter, Stanley Kubrick: A Biography (New York: HarperCollins, 1 998), 163. That Mr. Haze was, in Charlotte's words "in insurance," "left [her] well-provided for," and "was a lovely human being" (i.e. a mensch), could also be read as further Jewish clues.

${ }^{65}$ Hilberg, 668, 652, 658. In this respect, it is significant that the daily continuity report for this shot, dated 24 Jan. 1961, reported, "The dialogue off screen is not the dialogue used in the shot - that is only very approximately - Humbert speaking with a German accent, and calling himself Rommel etc. simply to give reaction to Lolita." Daily continuity reports, SK/ 1o/3/4, SKA. As if reinforcing this underlying German subtext, prior to Lolita, Mason had starred as Field Marshal Erwin von Rommel in The Desert Fox (1951) and The Desert Rats (1953). 


\section{Nathan Abrams}

the concentration camps." ${ }^{\prime 6}$ Friedan went on to explore this analogy for several pages, and then continued to use the phrase "comfortable concentration camps" to refer to suburban homes throughout the rest of the book.

Furthermore, in another shift from the novel, in the film Humbert lies on the marital bed contemplating murdering Charlotte. In the foreground, a gun is on the bedside table. The following conversation, transposed almost verbatim from the novel, takes place:

Charlotte: Darling, you've gone away.

Humbert: Just a minute, darling, I'm following a train of thought.

Charlotte: Am I on that train?

Humbert: Yes.

Humbert's thoughts, in the form of a voice-over narrative, confirm the suspicion: "No man can bring about the perfect murder. Chance, however, can do it. Just minutes ago she had said it wasn't loaded. What if I had playfully pulled the trigger then? She said it wasn't loaded. It belonged to the late Mr. Haze." The proximity of the gun, and Humbert's assumed thoughts, suggest a connection between trains and killing, what Cocks refers to as the "association with Nazi mechanics of murder that would show up in The Shining." 67 Again, to repeat a key point, in light of Winters's starring in The Diary only three years earlier, both of these conversations are particularly poignant and suggestive.

Significantly, Kubrick made various other changes which deviated from Nabokov's novel. In his close textual comparison of the novel and film, Greg Jenkins registered that

Kubrick's few changes work to the detriment of Charlotte, magnifying her undesirable qualities ... the Charlotte of the film is more brazen than the original, practically launching herself at Humbert. She is more noxious, rambling angrily in Winters' diva voice; the fictional Charlotte condemns her daughter in nothing but indirect quotations, a device that distances the reader from her fury. Again, the film craftily maneuvers us away from Charlotte; it asks us to take sides, to view her unsympathetically. ${ }^{68}$

These alterations served to emphasize the negative aspects of Charlotte's character. As Jenkins put it, "All these adjustments undercut the image, not sterling to begin with, of Charlotte ... rendering her less sympathetic, more vulgar." ${ }^{69}$ Richard Corliss adds, "Winters does appear to be twenty pounds

\footnotetext{
${ }^{66}$ Betty Friedan, The Feminine Mystique (New York: W. W. Norton, 1963), 294.

${ }^{67}$ Cocks, The Wolf at the Door, 103.

${ }^{68}$ Greg Jenkins, Stanley Kubrick and the Art of Adaptation: Three Novels, Three Films, (Jefferson: McFarland, 2007), 43-44.

${ }^{69}$ Ibid., 39-40.
} 
heavier, fifteen decibels higher and ten I. Q. points lower than Charlotte deserves." 70

Contemporary reviewers, especially those who were part of the intelligentsia, certainly picked up on this characterization. Writing in Partisan Review, Pauline Kael described Charlotte as "the culture-vulture rampant ... Shelley Winters' Charlotte is a triumphant caricature, so overdone it recalls Blake's 'You never know what is enough until you know what is enough."' 71 Arthur Schlesinger Jr. felt, meanwhile, that "Winters, as Lolita's mother, gives the performance of her life, laying bare with delicate exactitude the genteel pretension, the tremulous hope and prurient passion of what Nabokov apparently regards as the typical American middle-class woman., ${ }^{2}$ Finally, Dwight Macdonald opined, "Miss Winters plays her so fortissimo that she becomes a brawling Bronx fishwife whom one cannot imagine having poor Charlotte's cultural pretensions." 73 Indeed, he labelled her a "Monsterette."74 Macdonald misses the point that her casting intentionally transformed Charlotte from genteel to brawling, but he does inadvertently pick up on the implicit Jewishness of her character in locating her in the Bronx, where Kubrick grew up. Again, a brief glimpse of Kubrick's intentions is seen in his notes, where he refers to Charlotte's "ugliness." 75 At the same time, Kubrick coaxed a performance out of Winters that emphasized Charlotte's worst qualities. This led her to reflect,

I think the role of Charlotte in Lolita is one of the best performances I ever gave in any medium. She is dumb and cunning, silly, sad, sexy, and bizarre, and totally American and human. Until I saw the whole film cut together, I did not realize the gift that Kubrick had given me. I was enchanted with Charlotte and very proud of her. Kubrick had the insight to find the areas of me that were pseudointellectual and pretentious. We all have those things in us. ${ }^{76}$

A later, and similar, Kubrick casting decision supports this reading. Winters's role anticipates a comparable choice he took concerning the casting of Miriam Karlin in his A Clockwork Orange (197I). Before attacking Miss Weathers, the "Cat Lady" (played by Karlin), Georgie (James Marcus) justifies robbing her because her house "is full up with like gold, and silver, and like jewels." Cocks comments,

That this might be an echo of a common stereotype of Jews is suggested by the fact the woman is played by Miriam Karlin. Karlin is a British actress active in Jewish causes

\footnotetext{
${ }^{70}$ Corliss, Lolita, $4 \mathrm{I}$.

${ }^{71}$ Pauline Kael, "Movie Chronicle: Little Men," Partisan Review, 29, 4 (1962), 564-77, 57 I.

${ }^{72}$ Arthur Schlesinger Jr., "Little Women," Show Magazine, July i 962, 29.

${ }^{73}$ Dwight Macdonald, "Of Nymphets and Monsterettes," Esquire, Sept. 1962, Press Binder, SK/ I $/ 6 / 3$ iii, SKA. ${ }^{74}$ Ibid.

${ }^{75}$ Kubrick, "Last Scene Notes," n.d., SK/ Io/ I/ I I , SKA. $\quad{ }^{76}$ Winters, Shelley II, 348.
} 
and a prominent member of the Anti-Nazi League, which was one of the responses to the stirrings of neo-fascism in Britain at the time. Her mother came to England from Holland, and had lost her entire family at Auschwitz. ${ }^{77}$

Furthermore, as Cocks has argued, since the Cat Lady is "by conventional Hollywood standards a less than physically and personally attractive person," the audience is not encouraged to sympathize with her-just like it is not with Charlotte Haze. ${ }^{78}$ Thus she fits into a pattern of "Kubrick's indirect insinuation of the issue of Jews and anti-Semitism." 79 In this respect, it is certainly significant that when Winters saw the film, she wrote to Kubrick praising it and jokingly asking why she had not been asked to play "the very British woman who gets raped in this film." ${ }^{\circ}$ Winters recalled, "He did not get the joke. He sent me back a very stern reply and informed me that he would cast me in any role I was suited for in any one of his films. And that was final." 8 I

The question remains, then, why did Kubrick create such a negative caricature of a Jewish woman and mother? One answer would be to suggest an emotional and psychological impulse of misogyny and self-hatred; that is, that after two marriages to two different Jewish women - he divorced Toba Metz in 1955 and Ruth Sobotka in $196 \mathrm{I}$ - Kubrick took a dim view of Jewish femininity, buying into the caricature of the JAM that had begun to emerge in the mid-i950s. Evidence that might fit this last assertion may lie in the fact that Kubrick married Christiane Harlan, a non-Jewish German woman, who grew up during the Third Reich, for his third (and last) wife. Christiane recalled how "I was the little girl who moved in where Anne Frank was pushed out." 82

However, this answer seems far too easy. Kubrick was close to his (Jewish American) mother Gertrude (and she to him). According to Kubrick's third wife, Christiane, his mother was still buying him clothes as late as 1957 and was "more up on his films" than his father. ${ }^{83}$ According to LoBrutto, she was an "intelligent" and "well-spoken woman" from whom "Kubrick had inherited his looks." ${ }^{4}$ Indeed, in the sole film in which Kubrick allowed someone to make the only formal record of him at work - Making The Shining ( 1980), directed by his daughter Vivian, Gertrude appears, paying an on-set visit to her son. She is seen discussing with Jack Nicholson the daily script changes and the meaning of the colour of the script pages. Kubrick played a heavy hand in its editing, so the final cut had his approval, indicating a certain warmth towards his mother.

\footnotetext{
${ }^{77}$ Ibid., $126-27$.

${ }^{79}$ Ibid., 126.

${ }^{81}$ Ibid.

${ }^{83}$ Cocks, The Wolf at the Door, 26.

${ }^{78}$ Cocks, The Wolf at the Door, 8.

${ }^{8 \circ}$ Winters, Shelley II, 360.

${ }^{82}$ LoBrutto, Stanley Kubrick, I 47.

${ }^{84}$ LoBrutto, 434.
} 
Rather, an alternative suggestion will be posited here, that it may well be that Kubrick was deliberately playful with that very JAM stereotype, using an underlying and Jewish-inflected humour to make emotional, cogent and deeply serious points about anti-Semitism. Much has been written about the function of stereotypes in general and Jewish ones in particular, especially how they perform cultural work in demonizing minority groups from the outside, and emotionally perpetuating group solidarity and continuity from the inside. As Bhabha suggests, the stereotype offers "a secure point of identification"; ${ }^{85}$ that is, emotional reassurance. Daniel Boyarin called this form of comfort "Jewisssance." ${ }^{86}$ Itself a play on the French term jouissance - literally translating as "orgasm," but also referring to physical or intellectual pleasure, delight, or ecstasy - Boyarin defined Jewissance as "a pleasure" that "brings to many men and women an extraordinary richness of experience and a powerful sense of being rooted somewhere in the world, in a world of memory, intimacy, and connectedness." 87

Yet, on a deeper level, stereotypes contain a "surplus value," which provides "enjoyment or jouissance [and] enables us to understand the logic of exclusion." 88 Bhabha similarly suggested that the stereotype is characterized by a "productive ambivalence" between "pleasure and desire" and "power and domination." 89 In other words, stereotypes are enjoyed because they allow us to see contested images at work and understand their ideological implications. They entertain us, as well as serve to ridicule the logic of exclusion. ${ }^{\circ}$ This use of Jewish stereotypes by Kubrick, then, reveals a deeper strategy beyond Jewissance and pleasure. The reversal of insult, or "victim humour," is a technique against anti-Semitism, to "disguise the aggression and hostility by turning it on oneself." ${ }^{1}$ This is comparable to what Michel Foucault labelled a "reverse discourse," which seeks to "demand that its legitimacy ... be acknowledged, often in the same vocabulary, using the same categories by which it was ... disqualified."92 Bhabha pointed out how "the same stereotype maybe read in a contradictory way or, indeed, be misread."93 This "reverse stereotype," then, achieves the status of what Foucault called "a hindrance, a stumbling

${ }^{85}$ Bhabha, 99, original emphasis.

${ }^{86}$ Daniel Boyarin, Unheroic Conduct: The Rise of Heterosexuality and the Invention of the Jewish Man (Berkeley: University of California Press, 1997), xxiii. ${ }^{87}$ Ibid.

${ }^{88}$ Slavoj Žižek, The Sublime Object of Ideology (London: Verso, 1989), xi.

${ }^{89}$ Bhabha, 96.

${ }^{90}$ Vasiliki P. Neofotistos, "The Muslim, the Jew and the African American: America and the Production of Alterity in Borat," Anthropology Today, 24, 4 (2008), 13-17, I6-1 7.

${ }^{91}$ A. A. Berger, Jewish Jesters: A Study in American Popular Comedy (Cresskill, NJ: Hampton Press, 200I), 9-1 8, 9.

${ }^{92}$ Michel Foucault, The History of Sexuality, Volume I, An Introduction, trans. Robert Hurley (London: Penguin, I990), I O I.

${ }^{93}$ Bhabha, 100. 
block, a point of resistance and a starting point for an opposing strategy."94 $\mathrm{Or}$ what Sigmund Freud described as "a rebellion against authority, a liberation from its pressures," 95 glossed by Bhabha as "a strategy of cultural resistance and agency committed to a community's survival." 96

As we have seen with the character of Charlotte, reverse stereotypes may take the form of "mimicry," 97 which "is never a simple reproduction of those traits. Rather, the result is a 'blurred copy' ... that can be quite threatening. This is because mimicry is never very far from mockery, since it can appear to parody whatever it mimics." 98 The reverse stereotype and mimicry, therefore, was a means for Kubrick to draw upon his Jewish background and Yiddishkeit (Yiddish: "Jewishness" or "Jewish culture") as a means to mimic, mock and critique the representation of the Jewish woman, particularly at a time when explicit Jews, played by Jews, were not much in evidence in Hollywood cinema and when representations of the Holocaust and anti-Semitism were only really beginning to emerge into mass media in the United States. Furthermore, if, as has been argued, the way that Kubrick adapted Nabokov's novel retained its concerns with the Holocaust and anti-Semitism, it fit into a period from the early to mid-1960s when various Jewish American intellectuals, who had grown up while the Holocaust was happening, used Nazism to forge emotional and deeply personal expressions of identity.99

${ }^{94}$ Foucault, I00-I.

${ }^{95}$ Sigmund Freud, Jokes and Their Relation to the Unconscious (Harmondsworth: Penguin, 1994), I 49. $\quad{ }^{96}$ Bhabha, xvii. $\quad{ }^{97}$ Bhabha, I 23.

${ }^{98}$ Bill Ashcroft, Gareth Griffiths and Helen Tiffin, Post-colonial Studies: The Key Concepts (London: Routledge, 2000), I 39.

${ }^{99}$ See Kirsten Fermaglich, American Dreams and Nazi Nightmares (Waltham, MA: University Press of New England, 2006). 